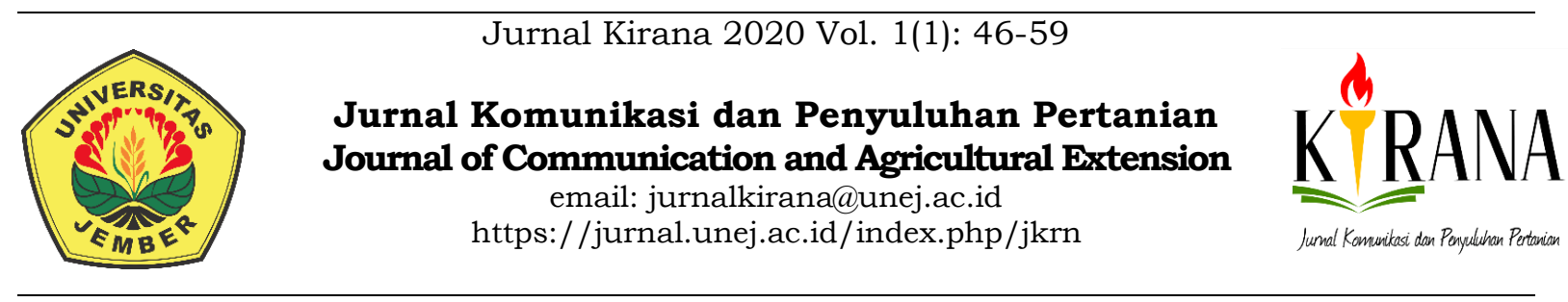

\title{
Dinamika Kelompok Tani dalam Mendukung Pengembangan Klaster Kopi di Kabupaten Bondowoso
}

\section{Farmer Group's Dynamic in Supporting The Development of Coffee Clusters in Bondowoso District}

\section{Djoko Soejono $^{\circledR}$ dan Dimas Bastara Zahrosa ${ }^{1}$}

1 Program Studi Agribisnis Fakultas Pertanian Universitas Jember

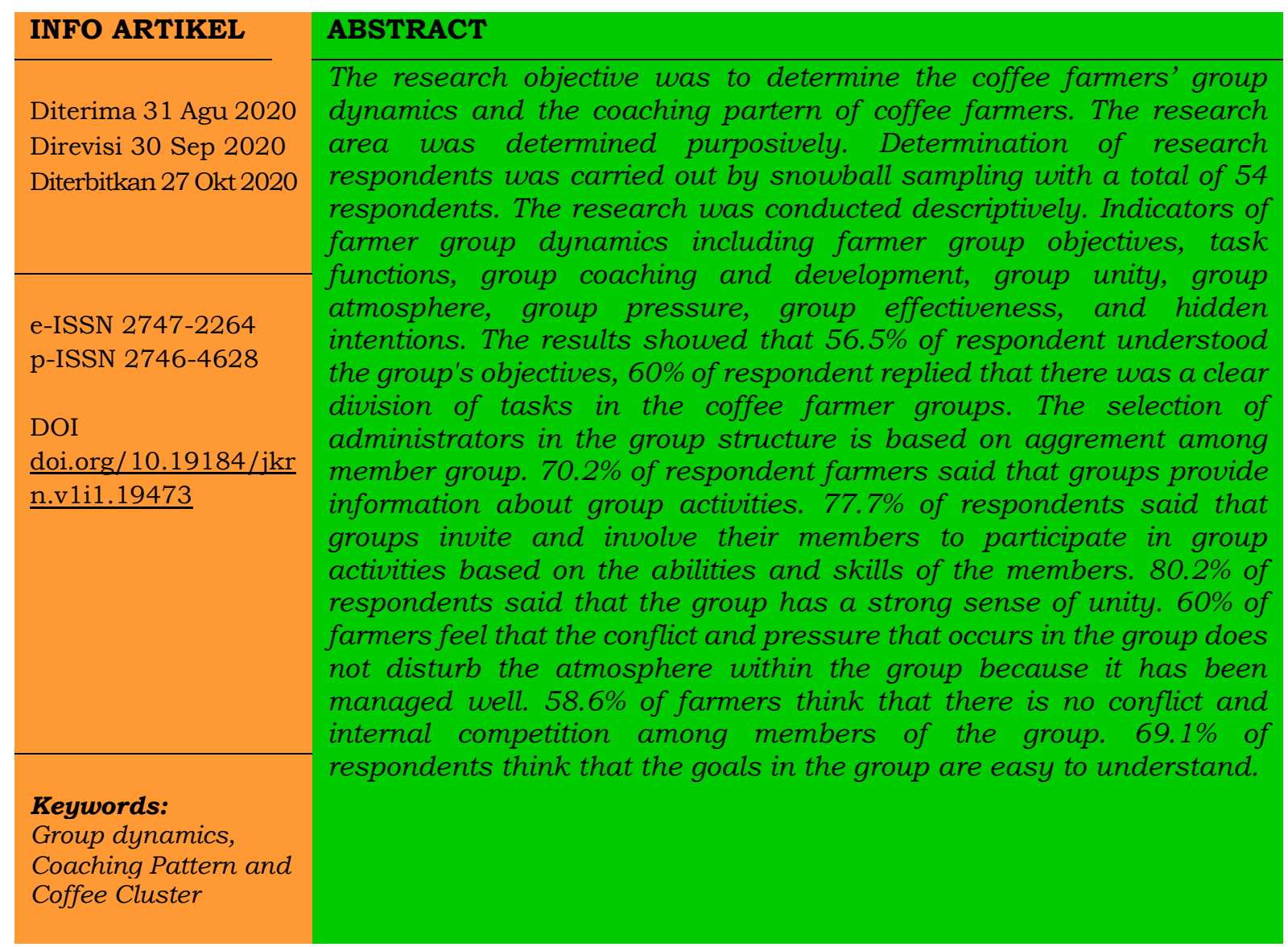

\enulis Koresponden :

E-mail : soejono_djoko@yahoo.co.id 


\begin{tabular}{|c|c|}
\hline & ABSTRAK \\
\hline $\begin{array}{l}\text { Kata kunci: } \\
\text { Dinamika Kelompok, } \\
\text { Pola Pembinaan dan } \\
\text { Cluster Kopi }\end{array}$ & $\begin{array}{l}\text { Tujuan penelitian adalah mengetahui dinamika kelompok tani kopi } \\
\text { dan Pola pembinaan kelompok tani kopi. Penentuan daerah penelitian } \\
\text { dilakukan secara purposive. Penentuan responden penelitian } \\
\text { dilakukan dengan snowball sampling dengan jumlah responden } \\
\text { sebanyak } 54 \text { orang. Penelitian dilakukan secara deskriptif. Indikator } \\
\text { dalam penelitian ini meliputi tujuan kelompok tani, fungsi tugas, } \\
\text { pembinaan dan pengembangan kelompok, kesatuan kelompok, } \\
\text { suasana kelompok, tekanan kelompok, efektivitas kelompok, dan } \\
\text { maksud terselubung. Hasil penelitian menunjukkan bahwa sebesar } \\
56,5 \% \text { petani responden memahami tentang tujuan kelompok, 60\% } \\
\text { petani responden mengatakan terdapat pembagian tugas yang yang } \\
\text { jelas pada kelompok tani kopi. Pemilihan pengurus dalam struktur } \\
\text { kelompok didasarkan pada keputusan bersama dan disepakati oleh } \\
\text { seluruh anggota. } 70,2 \% \text { petani responden mengatakan bahwa fungsi } \\
\text { kelompok dalam memberikan informasi tentang kegiatan kelompok } \\
\text { selalu dijalankan. 77,7\% petani responden mengatakan bahwa } \\
\text { kelompok mengajak atau melibatkan anggotanya sesuai kemampuan } \\
\text { untuk berpartisipasi dalam kegiatan kelompok. 80,2\% petani } \\
\text { responden mengatakan bahwa kelompok memiliki kesatuan dan } \\
\text { persatuan yang sangat kompak. 60\% petani merasa konflik dan } \\
\text { tekanan yang terjadi tidak mengganggu suasana di dalam kelompok } \\
\text { karena telah dikelola dengan baik. 58,6\% petani berpendapat bahwa } \\
\text { tidak terdapatkonflik dan persaingan internal dalamkelompok. 69,1\% } \\
\text { responden menganggap bahwa tujuan dalamkelompok ialah mudah } \\
\text { dimengerti atau dipahami. }\end{array}$ \\
\hline
\end{tabular}

\section{PENDAHULUAN}

Kopi merupakan salah satu komoditas pertanian di subsektor perkebunan mempunyai tantangan besar untuk dikembangkan, khususnya dalam usaha meningkatkan keunggulan kompetitif dan dayasaing komoditas kopi yang bermuara pada keberlanjutan usaha dari pekebun. Peluang untuk peningkatan keberlanjutan perlu diwujudkan secara optimal oleh pekebun khususnya petani dengan sebaik-baiknya. Peluang ini salah satunya dapat diwujudkan dilakukan dengan meningkatkan keunggulan komoditas kopi. Menurut Erdiansyah \& Yusianto (2012) Kopi merupakan produk perkebunan yang digunakan sebagai minuman penyegar. Karena fungsinya sebagai minuman penyegar maka harga kopi dinilai dari mutu fisik dan cita rasanya. Untuk menciptakan cita rasa yang baik diperlukan biji kopi berkualitas. Biji kopi tersebut didapatkan dengan budidaya yang baik dan faktor lingkungan yang ada pada daerah tersebut harus mendukung.

Kabupaten Bondowoso sebagai salah satu wilayah yang memiliki dataran tinggi dengan variasi topografi antara datar, bergelombang dan berbukit serta dikelilingi oleh pegunungan Ijen-Raung yang pada kenyataannya telah memberikan bukti sebagai potensi alam yang dapat dimanfaatkan secara optimal melalui pengembangan perkebunan kopi, yaitu baik perkebunan rakyat, pemerintah maupun swasta. Pengembangan komoditas menghadapi berbagai tantangan yang dasarnya bersumber dari permasalahan fundamental, yaitu permasalahan yang bersenyawa dengan aspek struktural bahkan kultural. 
Permasalahan struktural dapat dilihat dari praktek dualistik. Umumnya perkebunan rakyat dicirikan lemah dalam akses permodalan, teknologi dan manajemen, berperan sebagai penyedia bahan baku bagi perusahaan besar yang menguasai kegiatan pengolahan dan pemasaran, termasuk dinamika kelembagaan tingkat petani. Menurut Hermanto (2007) kelompok tani merupakan kelembagaan tani yang langsung mengorganisir para petani dalam mengembangkan usahataninya. Kelompok tani merupakan organisasi yang dapat dikatakan berfungsi dan ada secara nyata, disamping berfungsi sebagai wahana penyuluhan dan penggerak kegiatan anggotanya. Menurut Margono (2000) kelompok tani masih di gunakan sebagai pendekatan utama dalam kegiatan penyuluhan pertanian. Pendekatan kelompok di pandang efisien dan dapat menjadi media untuk terjadinya proses belajar dan berinteraksi dari para petani, sehingga diharapkan terjadi perubahan perilaku petani kearah yang lebih baik atau berkualitas. Demikian, kelompok tani memiliki kedudukan strategis dalam mewujudkan petani yang berkualitas. Petani yang berkualitas antara lain dicirikan oleh adanya kemandirian dan ketangguhan dalam berusahatani. Menurut Leilani \& Hasan (2006) terdapat beberapa unsur dalam dinamika kelompok adalah : (a) tujuan kelompok; (b) struktur kelompok; (c) fungsi tugas; (d) pembinaan dan pengembangan kelompok; (e) kekompakan kelompok; (f) suasana kelompok; (g) tekanan pada kelompok; (h) keefektifan kelompok dan (i) maksud terselubung. Tujuan penelitian ini adalah (1) menganalisis dinamika kelompoktani kopi arabika Bondowoso; dan (2) mendiskripsikan pola pembinaan dan pengawasan pengembangan kopi arabika Bondowoso.

\section{METODOLOGI}

Daerah penelitian ditentukan secara purposive Nazir (2009) yaitu di wilayah Kabupaten Bondowoso sebagai sentra penghasil kopi dan telah mendapat sertifikat pengakuan Indikasi Geografis Kopi Arabika Ijen-Raung dari Dirjen Haki. Metode yang digunakan dalam penelitian ini merupakan metode deskriptif. Menurut Nawawi (1998) metode diskriptif diartikan sebagai prosedur pemecahan masalah yang diselidiki, dengan menggambarkan atau melukiskan keadaan subyek atau obyek penelitian (seseorang, lembaga, masyarakat dan lain-lain) pada saat sekarang berdasarkan fakta-fakta yang tampak atau sebagaimana adanya. Untuk mendeskripsikan fakta-fakta tersebut, pada tahap permulaan tertuju pada usaha mengemukakan gejala-gejala secara lengkap di dalam aspek yang diselidiki agar jelas keadaan atau kondisinya. Metode deskriptif memusatkan perhatiannya pada penemuan fakta-fakta (fact finding) sebagaimana keadaan sebenarnya.

Teknik pengambilan data usahatani pada penelitian ini adalah dengan menggunakan Purposive Sampling. Yaitu menentukan sampel berdasarkan ciri bahwa lembaga tersebut merupakan kelompoktani kopi. Setelah diketahui ciri-ciri dari sampel tersebut maka langkah selanjutnya yang dapat dilakukan adalah mencari sampel dengan menggunakan metode snowball sampling. Menurut Umar (2003) snowball sampling adalahs teknik penentuan sampel yang mula-mula jumlahnya kecil, kemudian sampel ini disuruh memilih responden lain untuk dijadikan sampel lagi, begitu seterusnya sehingga jumlah sampel terus menjadi banyak. 


\section{PEMBAHASAN}

\section{Tingkat Dinamika Kelompok Tani Kopi di Kabupaten Bondowoso}

Penentuan dalam tingkat aktivitas anggota kelompok tani menggunakan indikator-indikator dalam dinamika kelompok melalui pendekatan secara psikososial. Indikator yang dimaksud meliputi tujuan kelompok tani, fungsi tugas, pembinaan dan pengembangan kelompok, kesatuan kelompok, suasana kelompok, tekanan kelompok, efektivitas kelompok, dan maksud terselubung. Peneliti menganggap bahwa indikator-indikator yang digunakan telah dapat mewakili untuk menganalisis aktivitas anggota kelompok tani. Tingkat dinamika kelompok sangat menentukan peran serta dan keefektifan para anggota kelompok dalam menyerap inovasi yang disampaikan oleh PPL. Tingkat dinamika kelompok tani dalam penelitian ini dapat dilihat pada tabel berikut:

Tabel 1. Hasil Analisis Tingkat Dinamika Kelompok Tani Kopi Kabupaten Bondowoso

\begin{tabular}{llrr}
\hline No. & \multicolumn{1}{c}{ Dinamika } & Jumlah (orang) & \multicolumn{2}{c}{ Persentase (\%) } \\
\hline 1 & Rendah & 0 & 0 \\
2 & Sedang & 18 & 33,3 \\
3 & Tinggi & 36 & 66,7 \\
\hline & Jumlah & 54 & 100 \\
\hline
\end{tabular}

Berdasarkan tabel 1. dapat diketahui bahwa dinamika kelompok secara keseluruhan pada kelompok tani kopi di wilayah klaster kopi Kabupaten Bondowoso terbagi menjadi dua yakni termasuk dalam kategori sedang dan tinggi. Hal ini tidak terlepas dari peran anggota kelompok tani kopi itu sendiri serta peran kerja dari pengurus kelompok tersebut. Hubungan yang harmonis dan seringnya interaksi atau komunikasi yang terjadi antar anggota, pengurus dengan anggota, maka akan semakin mendorong anggota untuk berani menuangkan ide atau pendapatnya tentang berbagai hal, baik dalam usahatani kopi maupun dalam berbagai hal yang menyangkut kegiatan kelompok. Komunikasi dan interaksi antar anggota kelompok tani kopi tidak hanya terbatas dalam pertemuan kelompok, melainkan dapat terjadi kapan saja ketika para anggota petani koppi di wilayah klaster kopi membutuhkan berbagai informasi dan penyelesaian masalah pertanian yang petani kopi hadapi. Adapun penjelasan untuk masing-masing indikator dalam dinamika kelompok tani kopi yang ada di wilayah klaster kopi Kabupaten Bondowoso.

1. Tujuan Kelompok

Hasil penelitian menunjukkan bahwa sebesar 56,5\% petani responden memahami tentang tujuan kelompok, hal ini diketahui bahwa petani paham tujuan adanya kelompok dan mereka tergabung dalam kelompok tersebut. Petani yang mengikuti kelompok tani nantinya juga berharap tujuan mereka dapat tercapai pula pada saat ikut bergabung dalam kelompok tani. Sebesar $36,1 \%$ petani responden kurang memahami tentang tujuan kelompok, hal ini mengindikasikan bahwa sebagian petani hanya ikut tergabung dalam kelompok namun tidak memahami sepenuhnya tentang tujuan kelompok. Selanjutnya, sebesar $7,4 \%$ petani responden menyatakan tidak memahami tentang tujuan kelompok. 
Sebesar 78,6\% petani responden mengatakan bahwa kegiatan kelompok sejalan dengan tujuan yang ingin dicapai, hal ini diketahui bahwa petani merasa sesuai dengan kegiatan-kegiatan yang diadakan oleh kelompok. Petani yang mengikuti kegiatan kelompok merasakan ada tambahan ilmu tentang usahatani kopi seusai diadakan pelatihan oleh kelompok tani. Sebesar 20,7\% petani responden menyatakan bahwa kegiatan yang dilakukan kelompok kurang sesuai dengan tujuan yang ingin mereka capai, hal ini mengindikasikan bahwa sebagian petani kurang merasa sesuai dengan kegiatan-kegiatan ang dilakukan oleh kelompok. Selanjutnya, sebesar $0,7 \%$ petani responden menyatakan bahwa kegiatan yang dilakukan oleh kelompok tani tidak sesuai dengan tujuan yang dicapai.

Dari seluruh tujuan yang telah ditetapkan di dalam kelompok, diharapkan untuk dapat digunakan dalam mengukur kemajuan yang telah dicapai selama ini. Menurut pendapat responden, 52,3\% petani setuju bahwa tujuan yang telah ditetapkan dapat digunakan untuk mengukur kemajuan yang telah dicapai. Sedangkan $44,5 \%$ petani berpendapat bahwa tujuan yg sudah ditetapkan kurang dapat digunakan untuk mengukur kemajuan yang telah dicapai kelompok. Hanya 3,2\% petani yang beranggapan bahwa tujuan yang telah ditetapkan tidak dapat mengukur kemajuan yang telah dicapai kelompok.

Salah satu alasan petani bersedia bergabung dengan kelompok tani adalah adanya kesesuaian antara tujuan yang dimiliki kelompok dengan tujuan pribadi petani. Dari hasil penelitian yang di lakukan, $67,2 \%$ petani merasa bahwa tujuan pribadi petani dalam usaha ekonomi rumah tangga sesuai dengan tujuan kelompok. Sedangkan 29,8\% petani merasakan kurangnya kesesuaian tujuan kelompok dengan tujuan pribadi petani dalam usaha ekonomi rumah tangga. Hanya 3\% petani yang merasakan ketudak sesuaian antara tujuan pribadi petani dengan tujuan kelompo dalam hal usaha ekonomi rumah tangga.

Berdasarkan hasil penelitian, $77,7 \%$ responden berpendapat bahwa tujuan dari kelompok mampu memberikan motivasi serta semangat kepada petani dalam memenuhi kebutuhannya. Sedangkan 20,9\% petani merasa kurang adanya motivasi yang di dapat dari tujuan kelompok dalam memenuhi kebutuhan. Hanya $1,4 \%$ petani yang merasa tidak mendapatkan motivasi dalam memenuhi kebutuhan petani dari tujuan kelompok tani.

2. Struktur Kelompok

Hasil penelitian menunjukkan bahwa $60 \%$ petani responden mengatakan terdapat pembagian tugas yang yang jelas pada kelompok tani kopi. Pemilihan pengurus dalam struktur kelompok didasarkan pada keputusan bersama dan disepakati oleh seluruh anggota. Keputusan bersama diambil agar tidak ada kesenjangan antara anggota kelompok tani kopi di wilayah klaster kopi Kabupaten Bondowoso. Sebesar 37\% petani responden mengatakan bahwa terdapat pembagian tugas tapi tidak jelas pembagiannya. Hal ini dilandasi kurangnya pengetahuan petani tentang struktur organisasi dalam kelompok. Selanjutnya sebesar 3\% petani responden mengatakan tidak terdapat pembagian tugas dalam kelompok tani mereka. 
Keterlibatan anggota kelompok didalam pengambilan keputusan sangat diperlukan, sehingga tidak terdapat kesenjangan dalam penyampaian pendapat dan pengambilan keputusan. Sebanyak $62 \%$ petani responden mengatakan sebagian besar anggota terlibat dalam pengambilan keputusan kelompok. Hal ini menunjukan bahwa sebagian besar anggota kelompok memiliki kesempatan yang sama untuk ikut andil dalam pengambilan keputusan kelompok. Sebesar 31,7\% petani responden mengatakan hanya sebagian kecil anggota yang terlibat dalam pengambilan keputusan kelompok. Hal ini menunjukan bahwa tidak semua anggota kelompok ikut berpartisipasi dalam pengambilan keputusan di kelompok tani kopi. Sebanyak $6,3 \%$ petani responden mengatakan anggota tidak dilibatkan dalam pengambilan keputusan kelompok.

Kelancaran informasi yang terjadi dalam suatu kelompok sangat menentukan keberhasilan suatu kelompok untuk mencapai tujuannya, komunikasi yang baik akan membangun kolaborasi antar anggota kelompok yang baik. Petani responden sebanyak 65\% mengatakan informasi sampai pada sebagian besar atau semua anggota kelompok. Sebanyak 32\% petani responden mengatakan informasi hanya sampai pada sebagian kecil anggota kelompok, atau dapat dikatakan informasi tidak tersebar pada seluruh anggota kelompok. Sebanyak 3\% petani responden mengatakan informasi hanya sampai pada ketua dan pengurus kelompok, dengan artian anggota kelompok tidak tahu tentang informasi tersebut.

Rasa solidaritas pada suatu kelompok akan menumbuhkan rasa saling tolong menolong dan ada rasa kebersamaan antar anggota kelompok maupun anggota kelompok pada pengurus kelompok tani kopi, sehingga masalah yang dihadapi oleh salah satu petani atau anggota kelompok tani akan di selesaikan lebih mudah. Petani responden sebanyak $76 \%$ petani responden mengatakan solidaritas dan rasa kebersamaan atau kekompokan dalam kelompok sangat kuat. Hal ini menunjukan bahwa sebagian besar anggota kelompok memiliki rasa kebersamaan yang tinggi kepada sesama anggota kelompok ataupun antara anggota dengan pengurus kelompok. Sebesar 22,6\% petani responden mengatakan solidaritas dan rasa kebersamaan atau kekompokan dalam kelompok kurang kuat. Sebanyak 1,4\% petani responden mengatakan solidaritas dan rasa kebersamaan atau kekompokan dalam kelompok tidak kuat.

Sebanyak $64.8 \%$ petani responden mengatakan ada ukuran dan aturan yang dipakai dalam kelompok untuk ditaati bersama, dengan adanya aturan ini diharapkan anggota akan mematuhi aturan tersebut guna kebaikan kelompok. Petani responden sebanyak 27,2\% mengatakan ada ukuran dan aturan yang dipakai dalam kelompok, namun perautan tersebut tidak ditaati oleh anggota kelompok. Sebanyak 8\% petani responden mengatakan tidak ada ukuran dan aturan yang dipakai dalam kelompok untuk ditaati atau dilakukan bersama oleh anggota kelompok kopi di wilayah klaster kopi Kabupaten Bondowoso.

Sarana prasarana merupakan salah satu kebutuhan yang penting untuk dipenuhi, sarana prasarana sangat penting adanya untuk mencapai suatu tujuan, terpenuhinya sarana dan prasarana sangat diperlukan oleh petani untuk melakukan usahatani khususnya kopi. Sebanyak $56,8 \%$ petani responden mengatakan sarana dan prasarana yang mendukung terjadinya interaksi sangat memadai. Selanjutnya, sebesar $42,4 \%$ petani responden mengatakan terdapat 
sarana dan prasarana yang mendukung terjadinya interaksi namun kondisinya kurang memadai. Sebanyak 0,8\% petani responden mengatakan tidak ada sarana dan prasarana untuk mendukung terjadinya interaksi antar anggota kelompok.

Tujuan merupakan hal yang harus dicapai melalui proses yang dilakukan oleh seseorang untuk mencapai suatu keinginan, untuk mengetahui apakah tujuan atau keinginan tersebut sudah dicapai atau belum maka perlu adanya tindakan evaluasi yang dapat menilai apakah tujuan tersebut telah dicapai atau belum. Sebanyak $54,1 \%$ petani responden mengatakan tujuan sudah tercapai, dan dilakukan monitoring ataupun evaluasi secara rutin. Sebesar 39,3\% petani responden mengatakan tujuan belum tercapai sepenuhnya dan dilakukan monitoring serta evaluasi. Sebanyak $6,6 \%$ petani responden mengatakan tujuan tidak tercapai dan tidak dilakukan monitoring dan evaluasi. Sebanyak $21,5 \%$ petani responden mengatakan jumlah anggota kelompok dalam kelompoknya adalah 2-12 anggota. Selanjutnya Sebesar 42,8\% petani responden mengatakan jumlah anggota kelompok 13-23 anggota. Sedangkan Sebanyak 35,7\% petani responden mengatakan jumlah anggota kelompok antara 24-30 anggota.

3. Fungsi Tugas

Hasil penelitian menunjukkan bahwa sebesar $70,2 \%$ petani responden mengatakan bahwa fungsi kelompok dalam memberikan informasi tentang kegiatan kelompok selalu dijalankan. Responden petani sebanyak 29,8\% mengatakan bahwa fungsi kelompok dalam memberikan informasi tentang kegiatan kelompok kadang-kadang berjalan. Pemberian informasi terhadap seluruh anggota kelompok sangat penting, dimana intinya aliran informasi berjalan sudah sukup diterima diseluruh anggota kelompok tani.

Adanya koordinasi dalam kegiatan kelompok sangat dibutuhkan untuk mencapai kesepakatan bersama, koordinasi yang baik akan mendukung tercapainya tujuan kelompok. Sebanyak 56,3\% petani responden mengatakan kegiatan kelompok untuk mencapai kesepaatan bersama selalu berkoordinasi dan dikoordinasikan. Selanjutnya, sebesar 40,6\% petani responden mengatakan kegiatan kelompok untuk mencapai kesepaatan bersama kadang-kadang dikoordinasikan. Sebanyak $3,1 \%$ petani responden mengatakan kegiatan kelompok untuk mencapai kesepaatan bersama tidak ada koordinasi atau tidak dikoordinasikan.

Adanya masalah di suatu kelompok diperlukan suatu pemecahan dimana masalah tersebut menyangkut anggota kelompok ataupun kelompok. Adanya kelompok tani diharapkan masalah yang timbul dapat dipecahkan dengan mudah. Sebanyak $73,4 \%$ petani responden mengatakan kelompok selalu membantu memecahkan masalah anggotanya. Sebesar $24,5 \%$ petani responden mengatakan kelompok kadang-kadang menjalankan atau membantu memecahkan masalah anggotanya. Sebanyak 2,1\% petani responden mengatakan kelompok tidak pernah membantu memecahkan masalah anggotanya.

Salah satu fungsi kelompok yakni menumbuhkan rasa motivasi anggotanya, adanya kelompok tani diharapkan akan selalu meningkatkan motivasi anggota sehingga tujuan yang diinginkan dapat segera tercapai. Petani responden sebanyak 69,4\% mengatakan kelompok selalu menumbuhkan motivasi anggotanya. Sebesar $26,9 \%$ petani responden mengatakan kelompok 
kadang-kadang melakukan kegiatan untuk menumbuhkan motivasi anggotanya. Sebanyak 3,7\% petani responden mengatakan kegiatan kelompok untuk menumbuhkan motivasi tidak pernah dilakukan.

Fungsi kelompok salah satunya yakni memberikan rasa senang dan puas, pemberian rasa sengan dan puas ini dilakukan sebagai penghargaan atas hasil yang diperoleh anggota kelompok. Dari hasil penelitian sebanyak 62\% petani responden mengatakan kelompok dalam hal memberikan rasa senang dan puas terhadap hasil yang diperoleh berjalan dengan baik. Sebesar 31,7\% petani responden mengatakan dalam hal memberikan rasa senang dan puas terhadap hasil yang diperoleh kadangkadang berjalan. Sebanyak 6,3\% petani responden mengatakan kelompok dalam hal memberikan rasa senang dan puas terhadap hasil yang diperoleh tidak pernah berjalan.

Fungsi kelompok yang lain yakni dalam hal mengajak semua anggota kelompok untuk berpartisipasi dalam kegiatan kelompok. Dari hasil penelitian terdapat sebanyak $75,6 \%$ petani responden mengatakan kelompok dalam mengajak semua anggota untuk berpartisipasi dalam kegiatan kelompok berjalan dengan baik. Sebesar 19,2\% petani responden mengatakan kelompok dalam mengajak semua anggota untuk berpartisipasi dalam kegiatan kelompok kadang-kadang berjalan. Sebanyak 5,2\% petani responden mengatakan kelompok dalam mengajak semua anggota untuk berpartisipasi dalam kegiatan kelompok tidak pernah dijalankan.

Dari hasil penelitian $58,6 \%$ petani responden menyatakan jika ada pertanyaan yang belum jelas, maka akan selalu menjelaskan hal-hal yang dirasa belum jelas dan menjadi masalah pada anggota kelompok tani kopi di wilayah klaster kopi Kabupaten Bondowoso. Sebanyak 37,5\% petani responden mengatakan jika ada pertanyaan yang belum jelas, kadang-kadang memberikan penjelasan. Dari hasil penelitian 3,9\% petani responden menyatakan jika ada masalah atau hal yang belum jelas, maka tidak pernah memberikan penjelasan.

4. Pembinaan dan Pengembangan Kelompok

Hasil penelitian menunjukan sebesar $77,7 \%$ petani responden mengatakan bahwa kelompok mengajak atau melibatkan anggotanya sesuai kemampuan untuk berpartisipasi dalam kegiatan kelompok. Hal ini dapat dilihat dari anggota yang selalu dilibatkan pada setiap kegiatan-kegiatan yang diadakan oleh kelompok dimana anggota ikut dilibatkan sesuai dengan kemampuan anggotanya. Sebesar 18,7\% petani responden mengatakan bahwa kelompok hanya kadang-kadang melibatkan anggota untuk ikut berpartisipasi dalam kegiatan kelompok, sedangkan sebanyak 3,6\% petani responden mengatakan anggota tidak dilibatkan untuk berpartisipasi dalam kegiatan kelompok.

Sebesar $74,5 \%$ petani responden mengatakan bahwa upaya kegiatan atau aktivitas dalam kelompok berjalan dengan baik. Kegiatan dan aktivitas yang berjalan baik mengindikasikan adanya pembinaan dan pengembangan kelompok yang baik juga. Petani responden sebanyak $24,1 \%$ mengatakan bahwa upaya kegiatan atau aktivitas dalam kelompok kadang-kadang berjalan. Sebesar 1,4\% petani responden mengatakan bahwa upaya kegiatan atau aktivitas dalam kelompok tidak berjalan.

Berdasarkan hasil penelitian menunjukan sebesar $70 \%$ petani responden mengatakan bahwa koordinasi yang ada di dalam kelompok berjalan dengan baik. Koordinasi yang baik akan memudahkan kelompok dan anggotanya untuk mencapai tujuan kelompok secara bersama-sama. Petani responden sebanyak 27,8\% 
mengatakan bahwa koordinasi yang ada di dalam kelompok kadang-kadang dikoordinasikan. Sebesar $2,2 \%$ petani responden mengatakan bahwa tidak ada koordiasi didalam kelompok.

Sebesar $86 \%$ petani responden mengatakan bahwa komunikasi yang terjadi didalam kelompok berjalan dengan sangat baik. Komunikasi yang sangat baik akan memudahkan untuk informasi tersebar pada seluruh anggota kelompok. Petani responden sebanyak 9,8\% mengatakan bahwa komunikasi yang terjadi didalam kelompok berjalan kurang baik. Sebesar 4,2\% petani responden mengatakan bahwa komunikasi yang terjadi didalam kelompok tidak berjalan dengan baik.

Berdasarkan hasil penelitian yang dilakukan menunjukan sebesar 42,1\% petani responden mengatakan bahwa terdapat standar perilaku, nilai, dan norma yang jelas didalam kelompok. Petani responden sebanyak 49,1\% mengatakan bahwa terdapat standar perilaku, nilai, dan norma didalam kelompok namun tidak jelas. Selanjutnya sebesar $8,8 \%$ petani responden mengatakan bahwa tidak terdapat standar perilaku, nilai, dan norma didalam kelompok.

Berdasarkan hasil penelitian menunjukan sebesar $64,1 \%$ petani responden mengatakan bahwa upaya kelompok untuk mendapatkan anggota baru berjalan dengan baik. Kelompok melakukan kegiatan untuk mendapatkan anggota baru juga bertujuan untuk mengganti anggota lama yang sudah tidak ikut kelompok lagi. Petani responden sebanyak 32,1\% mengatakan bahwa upaya kelompok untuk mendapatkan anggota baru kadang-kadang berjalan. Sebesar 3,8\% petani responden mengatakan bahwa upaya kelompok untuk mendapatkan anggota baru tidak berjalan.

5. Kekompakan Kelompok

Berdasarkan hasil penelitian menunjukan sebesar $80,2 \%$ petani responden mengatakan bahwa kelompok memiliki kesatuan dan persatuan yang sangat kompak. Kelompok yang memiliki kekompakan yang baik maka akan memudahkan untuk mencapai tujuan kelompok tersebut. Petani responden sebanyak 19,2\% mengatakan bahwa kelompok memiliki kesatuan dan persatuan yang kurang kompak. Sebesar $0,6 \%$ petani responden mengatakan bahwa kelompok memiliki kesatuan dan persatuan yang tidak kompak.

Sebesar $70,3 \%$ petani responden mengatakan bahwa rasa memiliki, mempercayai, menghormati, dan mengasihi dalam kelompok terwujud. Rasa memiliki, mempercayai dan mengorhormati serta mengasihi yang muncul di dalam kelompok akan menimbulkan rasa nyaman berada di dalam kelompok. Petani responden sebanyak $29,7 \%$ mengatakan bahwa rasa memiliki, mempercayai, menghormati, dan mengasihi dalam kelompok kurang terwujud. Hal ini menunjukan bahwa masih terdapat sebagian petani yang tergabung dalam kelompok belum memiliki rasa memiliki dan rasa nyaman yang dirasakan oleh petani yang tergabung dalam kelompok di wilayah klaster kopi Kabupaten Bondowoso.

Berdasarkan hasil penelitian menunjukan sebesar $73,4 \%$ petani responden mengatakan bahwa kerjasama dan semangat saling membantu sangat terwujud. Rasa kebersamaan dan gotong royong serta saling membantu sudah dirasakan oleh anggota kelompok tani. Petani responden sebanyak $26,6 \%$ mengatakan bahwa 
kerjasama dan semangat saling membantu sangat terwujud. Hal ini menunjukan bahwa masih kurang terasanya rasa kebersamaan dan semangat di dalam kelompok tani kopi di wilayah klaster kopi Kabupaten Bondowoso.

Sebesar $78,1 \%$ petani responden mengatakan bahwa tingkat rasa kebersamaan dan kesamaan diantara anggota kelompok ada dan kuat. Rasa kebersamaan dan kesamaan sudah terjalin di dalam anggota kelompok sudah dirasakan ada dan kuat, hal ini data dilihat dari adanya rasa saling membantu antar anggota kelompok. Petani responden sebanyak 21,9\% mengatakan bahwa tingkat rasa kebersamaan dan kesamaan diantara anggota kelompok ada tapi masih kurang kuat. Hal ini menunjukan bahwa masih kurang terasanya rasa kebersamaan dan kesamaan didalam kelompok.

Berdasarkan hasil penelitian menunjukan sebesar $88,2 \%$ petani responden mengatakan bahwa kelompok dirasakan sangat harmonis. Keharmonisan hubungan antar anggota kelompok dirasakan sangat kental hal ini dapat dilihat pada hubungan dan rasa kebersamaan yang terjalin dalam kelompok tani kopi di wilayah klaster kopi Kabupaten Bondowoso. Petani responden sebanyak 11,8\% mengatakan bahwa suasana dalam kelompok dirasakan kurang harmonis. Hal ini menunjukan bahwa masih kurang terasanya rasa kebersamaan yang dirasakan oleh sebagian petani yang tergabung dalam kelompok tani.

6. Suasana Kelompok

Suasana yang diinginkan dalam kelompok tani di wilayah klaster kopi Kabupaten Bondowoso adalah dapat saling bertukar informasi dan berkomunikasi secara lancar, dapat dengan bebas mengutarakan pendapat yang dimilikinya, serta rasa nyaman ketika berada di dalam kelompok. Dengan adanya rasa nyaman dan serta kebebasan mengutarakan pendapat maka diharapkan segala aktifitas di dalam kelompok dapat berjalan dengan lancar dan menyenangkan. Hasil penelitian menunjukkan, dari 54 responden, sebesar $40 \%$ petani menyatakan bahwa konflik dan Tekanan yang terjadi di dalam kelompok cukup mengganggu suasana kelompok. Sedangkan sebesar $60 \%$ petani merasa konflik dan Tekanan yang terjadi tidak mengganggu suasana di dalam kelompok karena telah dikelola dengan baik.

Berdasarkan hasil penelitian, dari seluruh responden, terdapat $16 \%$ petani yang beranggapan bahwa suasana hubungan antara anggota kelompok kurang dekat antara satu anggota dengan anggota lain. Sedangkan 84\% petani menyatakan bahwa hubungan antar anggota dalam kelompok dapat dikatakan dekat, bahkan bersahabat satu dengan yang lainnya. Hal ini dapat di karenakan anggota kelompok yang bertempat tinggal berdekatan atau dapat disebut tetangga dan sling bertemu dan bersilaturahmi satu dengan yang lainnya.

Suasana yang dirasakan ketika petani berada di dalam kelompok dapat mempengaruhi perasaan yang dimiliki oleh petani, apakah mersa senang, nyaman atau sebaliknya, merasa terkekang dan merasa dikendalikan kelompok seingga membuat petani tidak betah berada di dalam kelompok. Dari hasil penelitian menunjukkan bahwa $82,5 \%$ petani merasa permisif dan diberi kebebasan kketika berada dalam kelompok. Sedangkan 17,5 persen petani lainya merasakan kuurangnya kebebasan di dalam kelompok karena adanya batasan-batasan yang dibuat oleh kelompok. 
Lingkungan yang menjadi tempat aktivitas kelompok merupakan faktor penting yang dapat mempengaruhi suasana di dalam kelompok. Adanya lingkungan aktivitas yang baik akan mampu menciptakan suasana yang baik pula, juga sebaliknya. Berdasrakan pendapat responden, 91\% petani merasa nyaman akan dengan lingkungan tempat aktivitas kelomok. Sedangkan 9\% petani menyatakan kurang nyaman dengan lingkungan tempat aktivitas kelompok saat ini.

Hasil penelitian yang telah dilakukan terhadap 54 responden menyatakan bahwa $81,6 \%$ petani merasa jalannya pengambilan keputusan, baik di dalam rapat maupun pada pertemuan lainnya dilaksanakan secara demokratis. Sedangkan $17,7 \%$ petani merasa kurangnya sikap demokratis dalam jalannya pengambilan keputusan didalam rapat maupun dalam pertemuan kelompok. Hanya $0,7 \%$ atau satu orang petani yang menyatakan bahwa jalannya pengambilan keputusan baik dalam rapatmaupun pertemuan lainnya dalam kelompok masih tidak demokratis.

7. Tekanan dalam Kelompok

Konflik dan persaingan internal di dalam kelompok merupakan hal yang wajar terjadi antar anggota, karena persaingan maupun konflik akan bersifat mendorong kelompok tani untuk dapat lebih maju. Melalui hasil penelitian, dapat diketahui bahwa 3,9\% petani merasakan bahwa konflik dan persaingan internal yang terjadi dalam kelompok dapat menimbulkan tekanan dan menghambat upaya pencapaian tujuan kelompok. Sedangkan 37,5\% petani beranggapan bahwa dampak konflik dan persaingan internal dalam kelompok masih dapat dikelola namun tidak dapat memacu upaya pencapain tujuan kelompok. Sebagian besar responnden, yaitu 58,6\% petani berpendapat bahwa tidak terdapat konflik dan persaingan internal dalam kelompok. Kalaupun konflik tersebut ada, maka dapat dikelola dengan baik dan mampu memacu upaya pencapaian tujuan kelompok.

Sebesar 69,4\% petani menyatakan bahwa pemberian hadiah dan penerapan sangsi dalam kelompok memiliki dampak positif untuk memacu petani dalam pencapaian tujuan kelompok. Sedangkan 26,9\% petani berpendapat bahwa pemberian hadiah dan penerapan sangsi dalam kelompok kurang mampu dalam memacu upaya pencapaian tujuan kelompok. Hanya 3,7\% petani yang menyatakan bahwa pemberian hadiah dan penerapan sangsi dalam kelompok tidakmemberikan dampak terhadap upaya memacu pencapaian tujuan kelompok.

8. Keefektifan Kelompok

Berdasarkan hasil penelitian yang dilakukan terhadap 54 responden, 69,1\% responden menganggap bahwa tujuan dalam kelompok ialah mudah dimengerti atau dipahami. Sedangkan 30,2\% petani menyatakan bahwa tujuan dalam kelompok masih kurang dapat dimengerti. Sebesar 0,7\% responden menganggap bahwa tujuan dalam kelompok ialah sulit dimengerti atau dipahami. Tujuan kelompok harus dibuat semudah mungkin untuk dipahami agar seluruh anggota kelompok dapat memahami seluruh tujuan kelompok dan dapat meningkatkan keefektifan kelompok dalam mencapai tujuan. 
Berdasarkan data yang di dapat melalui penelitian, 87,2\% petani diberikan kesempatan serta kebebasan dalam menyampaikan dan mengkomunikasikan ideide atau gagasan anggota kelompok guna kemajuan kelompok. Sedangkan 10,8\% petani menyatakan diberikan kesempatan untuk manyampaikan serta mengkomunikasin ide-ide atau gaasan yang dimilikinya, namun kesempatan yang diberikan dirasa masih terbatas. Hanya $2 \%$ petani yang merasa bahwa tidak diberikannya kesempatan untuk mengkomunikasikan ide-ide serta gagasan untuk kemajuan kelompok.

Sebesar $75 \%$ responden menyatakan bahwa pengambilan keputusan dalam kelompok sudah tepat dan fleksibel bagi anggota kelompok. Sedangkan 25\% responden merasa bahwa keputusan yang diambil kurang tepat dan kurang fleksibel. Pengambilan keputusan menjadi satu hal yang akan memberikan pengaruh besar bagi efektifitas kelompok. Pengambilan keputusan yang baik akan mampu memberikan efek baik bagi kelompok, dan sebaliknya.

Sebesar 68,5\% responde merasa bahwa kemampuan pemimpin dalam kelompok tani sudah sangat memadai. Artinya lebih dari setengah petani merasa puas atas kepemimpinan yang dilakukan oleh pemimpin kelompok. Sedangkan sebanyak $31,5 \%$ petani merasakan kurangnya kemampuan pemimpin dalam memimpin kelompok. Hal ini dirasakan oleh sebagian responden bahwa kepemimpinan yang ada saat ini masih kurang mampu untuk memimpin kelompok tani di wilayah klaster kopi Kabupaten Bondowoso.

Berdasarkan hasil penelitian, $72,3 \%$ petani memilih cara negosiasi dan saling ketergantungan antar anggota untuk mengatasi konflik dalam kelompok. Sebanyak $24,8 \%$ petani manyatakan bahwa ppenyelesaian konflik dalam kelompok dibutuhkan adanya negosiasi namun tidak memunculkan sikap sudah saling ketergantungan. Hanyak 4 petani atau 2,9\% petani menyatakan tidak adanya negosiasi antar petani. Hal ini menunjukan bahwa dibutuhkan negosiasi dan kerjasama antar anggota kelompok untuk menyelesaikan masalah-masalah yang timbul dalam kelompok atau anggota kelompok.

Melalui hasil penelitian, dapat dilihat bahwa $79,6 \%$ petani menyatakan bahwa mereka ingin terus bergabung dalam kelompok. Sedangkan 20,4\% petani menyatakan ada sedikit keinginan untuk terus bergabung dalam kelompok. Sebagian besar petani merasa inngin terus bersama dan bergabung dalam kelompok. Hal ini menunjukan bahwa ada timbal balik yang diterima oleh anggota kelompok yang bergabung dalam kelompok tani di wilayah klaster kopi Kabupaten Bondowoso

Berdasarkan hasil penelitian, 95\% petani menyatakn mendukung penuh segala aktivitas kelompok baik yang dilakukan sendiri mau pun berkelompok. Dukungan dari anggota kelompok sangat berharga dalam proses pencapaian tujuan kelompok. Sedangkan 5\% petani menyatakan kurang mendukung dalam segala aktivitas kelompok. Seluruh aktivitas yang ada dalam rencana kerja kelompok adalah perwujudan dari pencapaian tujuan kelompok. Dengan adanya dukungan penuh oleh anggota kelompok, anggota akan aktif dalam mengikuti aktivitas kelompok yang telah direncanakan.

Sebesar $88,8 \%$ responden menyatakan bahwa mereka memiliki kepercayaan terhadap kelompok. Sedangkan 10,5\% responden merasa kurang percaya terhadap kelompok. Hanya terdapat 1 orang atau $0,7 \%$ respoden yang merasa tidak percaya 
terhadap kelompok. Kepercayaan anggota kelompok terhadap kelompoknya maupun terhadap anggota kelompok lainnya akan mempengaruhi efektifitas kelompok dalam melaksanakan aktivitasnya. Dengan adanya rasa saling percaya, rasa nyaman akan muncul serta akan mengurangi munculnya resiko konflik di dalam kelompok.

Tingkat kepuasan merupakan hal yang relatif, sehingga kemungkinan kepuasan antara anggota satu dengan yang lainnya akan berbeda. Dari 54 responden yang diteliti, 65,7\% responden menyatakan puas dengan aktivitas yang dilakukan dalam kelompok. Hal ini disebabkan karna petani yang merasa mampu menyerap informasi baru yang diberikan oleh kelompok, sehingga menambah pengetahuan dan keterampilan yang dimiliki petani guna memperbaiki usaha taninya. Sedangkan 33,6\% reponden lainnya merasa kurang puas dengan aktivitas kelompok. Hanya 0,7\% responden yang merasa tidak puas dengan aktivitas yang dilakukan selama berada dalam kelompok.

Sebesar 63\% responden menyatakan tujuannya dalam kelompok telah tercapai. Sedangkan $25,2 \%$ responden menyatakan kurang tercapainya tujuan petani dalam kelompok. Hanya $11,8 \%$ responden yang merasa bahwa tujuannya di dalam kelompok masih belum tercapai. Hal ini menunjukan bahwa sebagian besar tujuan anggota kelompok tani sudah tercapai dengan ikut dalam kelompok tani, hanya sebagian kecil petani responden saja yang mengungkapkan bahwa tujuannya kurang tercapai dan belum tercapai.

9. Maksud Tersembunyi

Hasil penelitian yang telah dilakukan, 44,6\% petani menyatakan bahwa terdapat tujuan selain tujuan kelompok yang di sepakati bersama, namun tujuan tersebut memberikan dampak positif yaitu dapat memacu upaya pencapaian tujuan kelompok dan anggota kelompok. Selanjutnya, dari 54 responden terdapat $51,2 \%$ petani yang menyatakan bahwa mereka tidak memiliki tujuan selain tujuan kelompok dan hal itu tidak memberikan pengaruh maupun dampak apapun pada pencapaian tujuan kelompok dan anggota kelompok. Hanya 4,2\% petani yang menyatakan terdapat tujuan selain tujuan kelompok, bahkan tujuan tersebut berdampak negatif hingga menghambat pencapaian tujuan kelompok dan anggota kelompok lainnya.

Tujuan petani bergabung dengan kelompok tani, selain bertujuan untuk menambah pengethuan, juga untuk meningkatkan hasil panen yang berdampak pada peningkatan pendapatan. Petani berfikir dengan mengikuti kegiatan kelompok, maka apa yang menjadi keinginan petani dapat tercapai serta mendapatkan hasil yang diharapkan. Hal ini akan mendorong semakin aktifnya anggota kelompok dalam melaksankan tugas dan kegiatan kelompok tani yang akan meingkatkan kadinamisan suatu kelompok.

Sebesar $47,5 \%$ petani menyatakan bahwa adanya tujuan selain tujuan kelompok akan memberikan dampak untuk memacu pada uppaya pencapaian tujuan kelompok dan anggota kelompok lainnya. Sedangkan 46,6\% petani lainnya berpendapat bahwa adanya tujuan lain selain tujuan kelompok tidak akan memberikan dampak apapun terhadap pencapaian tujuan kelompok dan anggota kelompoknya. Hanya 5,9\% petani yang menyatakan adanya tujuan selain tujuan kelompok akan menghambat upaya pencapaian tujuan kelompok dan anggotanya. 


\section{Pola Pembinaan Kelompok Petani Kopi di Kabupaten Bondowoso}

Pembinaan kelompok merupakan hal yang sangat penting dilakukan oleh pemerintah untuk mendukung dan menyukseskan pengembangan program klaster kopi arabika di wilayah klaster kopi. Pembinaan yang pernah diterima oleh petani kopi arabika di Sumber Wringin diantarnya pelatihan mengenai stek batang, teknikteknik budidaya kopi, dan teknik pengolahan kopi arabika. Pelatihan stek batang bertujuan untuk mengenalkan kepada petani kopi arabika bagaimana cara pengembang biakan cara stek yang baik sehingga menigkatkan produktivitas tanaman kopi arabika. Pengenalan teknik-teknik budidaya kopi arabika dilakukan untuk mengajarkan kepada petani bagaimana teknik budidaya kopi yang baik sehingga memberikan hasil yang panen yang menguntungkan. Kegiatan pengenalan budidaya kopi arabika ini dimulai dari pemilihan varietas sampai dengan pemanenan hasil. Pelatihan mengenai teknik pengolahan kopi arabika juga bertujuan untuk bagaimana teknik pengolagan hasil kopi arabika sehingga sistem pengolahan kopi berjalan dengan baik dan memperoleh hasil yang maksimal.

Dampak positif yang diterima oleh petani adalah petani memiliki wawasan lebih mengenai teknik budidaya, teknik stek, dan pengolahan hasil yang baik. Bentuk pelatihan seperti ini dilakukan secara merata kepada semua petani sehingga tidak hanya sebagian petani saja yang dapat merasakan akan tetapi semuanya sehingga akan berdampak kepada wawasan petani yang luas akan kopi arabika. Harapan lain petani kepada pemerintah yakni adanya bantuan modal yang diberikan kepada petani berupa bibit, pupuk maupun obat-obatan sehingga dapat meringankan beban petani. Petani juga berharapa pemerataan akan bantuan yang diberikan oleh pemerintah dapat berjalan dengan baik sehingga dapat menunjang kegiatan budidaya kopi arabika khususnya di wilayah klaster kopi Kabupaten Bondowoso.

\section{KESIMPULAN}

Dinamika kelompok tani berdasarkan indikator tujuan kelompok, struktur kelompok, fungsi tugas, pembinaan dan pengembangan kelompok, kekompakan kelompok, suasana kelompok, tekanan dalam kelompok, efektifitas kelompok, maksud tersembunyi/terselubung, termasuk kategori dinamis; dan lembaga pemerintah dan stakeholder melakukan pembinaan kepada kelompok tani, terutama teknik budidaya dan pengolahan hasil/ agroindustri.

\section{DAFTAR PUSTAKA}

Erdiansyah, N. P., \& Yusianto. (2012). Hubungan Intensitas Cahaya di Kebun dengan Profil Cita Rasa dan Kadar Kafein Beberapa Klon Kopi Robusta. Pelita Perkebunan, 28(90), 14-22.

Hermanto, R. (2007). Rancangan Kelembagaan Tani dalam Implementasi Prima Tani di Sumatera Selatan. Analisis Kebijakan Pertanian, 5(2), 110-125.

Leilani, A., \& Hasan, O. D. S. (2006). Analisis Dinamika Kelompok pada Kelompok Tani Mekar Sari Desa Purwasari Kecamatan Dramaga Kabupaten Bogor. Penyuluhan Pertanian, 1(1), 18-27.

Margono, S. (2000). Metodologi Penelitian Pendidikan. Jakarta: Rineka Cipta.

Nawawi, H. (1998). Metode Penelitian Bidang Sosial.

Nazir, M. (2009). Metode Penelitian. Bandung: Ghalia Indonesia.

Umar, H. (2003). Metode Riset Bisnis. Jakarta: Gramedia Pustaka Utama. 